\title{
Statistical Prediction of Mineral Constituents in Cultivated Cucumber Crops Contiguous Cement
} Factory

\author{
C. Jemila Roshini ${ }^{1}$, B. Christudhas Williams ${ }^{2}$, R. Mary Suja ${ }^{3}$
}

${ }^{1}$ Research Scholar, Department of Botany and Research Centre, Scott Christian College (Autonomous), Nagercoil, Tamil Nadu, India ${ }^{2}$ Research Guide, Department of Botany and Research Centre, Scott Christian College (Autonomous), Nagercoil, Tamil Nadu, India ${ }^{3}$ Director William Research Centre, Nagercoil, Tamil Nadu, India

Abstract-Cement dust influence soil characteristics as well as morphological, anatomical, bio-chemical and physiological characteristics of plants. The change in morphological characteristics of plants due to cement dust pollution directly affects bio-chemical and physiological characteristics of plants, which in turn indirectly express their effect on morphological changes. Calcium content in the cucumber cultivated soil are positively correlated $0.86^{*}\left(A_{2}-A_{1}\right)$ at 0.05 level of significant, $0.98^{* *}\left(A_{3}-A_{4}\right)$ showed 0.01 level of significant; cucumber leaves are positively correlated $0.86^{*}\left(A_{2}-A_{1}\right)$ at 0.05 level of significant, $0.98^{* *}\left(A_{3}-A_{4}\right)$ showed 0.01 level of significant and cucumber fruits are positively correlated $0.90^{*}\left(A_{2}-A_{1}\right)$ at 0.05 level of significant and $0.98^{* *}\left(A_{3}-A_{4}\right)$ showed 0.01 level of significant.

Keywords-Cement pollution, cucumber, mineral constituents, bio-chemical, correlation.

\section{INTRODUCTION}

Cement industry plays a vital role in the imbalances of the environment produces air pollution hazards. Cement pollution became a major threat to the survival of plants in the industrial areas. Toxic compounds such as fluoride, magnesium, lead, zinc, copper, beryllium, sulphuric acid and hydrochloric acid were found to be emitted with cement manufacturing plants. Rapid industrialization and addition of the toxic substances to the environment are responsible for altering the ecosystem (Clayton, 1982). Cement dusted plants showed significant effect on the growth of plant species compared with non-cement dust plants. Lerman and Darley, (1974); Oblisami et al., (1978); Krishnamurthy and Rajachidambaram, (1986); Nandi et al., (1987); Prasad et al., (1991) reported that the cement exhausts dust affects developmental morphology, physical and chemical properties of the soil, plant colouration, morphology and crop productivity (Sarabai and Vivekanandan, 1992).

\section{MATERIALS AND METHODS}

The present investigation was done at the experimental field during summer and monsoon seasons at Thalaiyuth of Tirunelveli District. The cultivated crops around the vicinity of the factory 3-10 kilometers were considered as affected plants and beyond 10 kilometers as control plants whereas, vegetation was not found up to 1-3 kilometers from the factory due to heavy dusting of Cucumber (Variety Poinsettie).

\section{Estimation of Mineral Content}

The mineral contents $\mathrm{Ca}, \mathrm{Mg}, \mathrm{K}, \mathrm{Mn}, \mathrm{Al}, \mathrm{Fe}, \mathrm{Si}, \mathrm{Zn}$, $\mathrm{Cu}$ and $\mathrm{S}$ can be determined in acid digest of plant samples and soil with the help of Flame photometer or Atomic Absorption Spectrophotometer. Flame photometer is based on the principle that atoms of metallic elements which normally remain in ground state, under flame conditions, absorb energy when subjected to radiation of specific wavelength. The absorption of radiation is proportional to the concentration of atoms of that element. The absorption of radiation by the atoms is independent of the wavelength of absorption and temperature of the flame. First apply the respective cathode lamp for the particular nutrient bring determined and then feed the blank of the working standards to the flame photometer, Feed the aliquots (plant digest containing $0.5 \mathrm{~g}$ plant material in $50 \mathrm{ml}$ volume) directly or after a required dilutions of needed. Note down the readings (and dilution factor if dilution was done) on the flame photometer. Let the reading be ' $\mathrm{M}$ ' compare the reading of 
each element with their standard curves prepared already and calculate the concentration of each nutrient element in ppm.

Weight of plant material taken $=0.5 \mathrm{~g}$

Volume made after acid digestion $=50 \mathrm{ml}$

Dilution factor $=50 / 0.5=100$ times

\section{RESULT AND DISCUSSION}

Dust particles deposited on the plant surfaces and soil forms a crust on plant and land surface. A season with more wind velocity easily flows away through high velocity wind. So the deposition of dust particles became less. Calcium content in the cement polluted soil varied from $18.10 \pm 0.017$ in monsoon to $20.20 \pm 0.141$ in summer and control soil varied from $9.90 \pm 0.717$ in monsoon to $10.50 \pm 0.131$ in summer. Calcium content in the cement polluted cucumber leaves varied from $5.80 \pm 0.002$ in monsoon to $7.50 \pm 0.071$ in summer and control leaves varied from $4.30 \pm 0.717$ in monsoon to $4.80 \pm 0.051$ in summer. Calcium content in the cement polluted cucumber fruits varied from $6.30 \pm 0.071$ in summer to $6.50 \pm 0.032$ in monsoon and control fruits varied from $3.90 \pm 0.091$ in summer to $5.50 \pm 0.232$ in monsoon. The growth metabolic processes and yield of winter barley were found to be affected by the Duna cement (Borka, 1986).

Potassium content in the cement polluted soil varied from $13.50 \pm 0.132$ in monsoon to $16.50 \pm 0.002$ in summer and control soil varied from $5.20 \pm 0.081$ in summer to 5.30 \pm 0.112 in monsoon. Potassium content in the cement polluted cucumber leaves varied from $2.90 \pm 0.112$ in monsoon to $6.20 \pm 0.007$ in summer and control leaves varied from $0.30 \pm 0.008$ in monsoon to $2.60 \pm 0.062$ in summer. Potassium content in the cement polluted cucumber fruits varied from $4.20 \pm 0.117$ in summer to $4.80 \pm 0.016$ in monsoon and control fruits varied from $0.14 \pm 0.003$ in summer to $2.90 \pm 0.017$ in monsoon. Magnesium content in the cement polluted soil varied from $13.20 \pm 0.232$ in monsoon to $15.30 \pm 0.071$ in summer and control soil varied from $7.20 \pm 0.121$ in summer to $7.40 \pm 0.112$ in monsoon. Magnesium content in the cement polluted cucumber leaves varied from $2.90 \pm 0.002$ in monsoon to $5.20 \pm 0.005$ in summer and control leaves varied from $0.80 \pm 0.008$ in monsoon to $1.60 \pm 0.003$ in summer. Magnesium content in the cement polluted cucumber fruits varied from $3.90 \pm$ 0.003 in summer to $5.20 \pm 0.017$ in monsoon and control fruits varied from $0.50 \pm 0.005$ in summer to $1.90 \pm 0.001$ in monsoon. Lal and Ambasht, (1981) reported changes in the accumulation of mineral plant nutrients as a result of cement dust.

Manganese content in the cement polluted soil varied from $18.10 \pm 0.018$ in monsoon to $19.90 \pm 0.010$ in summer and control soil varied from $8.90 \pm 0.009$ in summer to $9.80 \pm$ 0.010 in monsoon. Manganese content in the cement polluted cucumber leaves varied from $3.60 \pm 0.003$ in summer to 4.60 \pm 0.004 in monsoon and control leaves varied from $0.80 \pm$ 0.001 in summer to $0.90 \pm 0.009$ in monsoon. Manganese content in the cement polluted cucumber fruits varied from $3.20 \pm 0.002$ in monsoon to $4.80 \pm 0.012$ in summer and control fruits varied from $0.70 \pm 0.001$ in summer to $1.00 \pm$ 0.001 in monsoon. Aluminum content in the cement polluted soil varied from $10.20 \pm 0.001$ in monsoon to $12.40 \pm 0.012$ during summer and control soil varied from $5.00 \pm 0.001$ in summer to $5.50 \pm 0.005$ in monsoon. Aluminum content in the cement polluted cucumber leaves varied from $4.20 \pm$ 0.004 in monsoon to $7.40 \pm 0.014$ in summer and control leaves varied from $2.80 \pm 0.002$ in monsoon to $4.80 \pm 0.004$ in summer. Aluminum content in the cement polluted cucumber fruits varied from $5.50 \pm 0.015$ in summer to 6.90 \pm 0.006 in monsoon and control fruits varied from $2.70 \pm$ 0.002 in summer to $5.10 \pm 0.010$ in monsoon. The increased level of Calcium, potassium, Magnesium, Manganese, Aluminum, Iron, Silica, Zinc, Copper and Sulphur in the soil, leaves, stem and fruits affect the vegetative growth, metabolism and yield of vegetables (Asubiojo et al., 1991; Ade- Ademilua and Umebese, 2007).

\section{Correlation co-efficient analysis}

Correlation co-efficient analysis was carried out to evaluate the inter-relationship between different variables showed both positive and negative correlation. Calcium content in the cucumber cultivated soil are positively correlated $0.86^{*}\left(\mathrm{~A}_{2}-\right.$ $\left.\mathrm{A}_{1}\right)$ at 0.05 level of significant whereas $0.98^{* *}\left(\mathrm{~A}_{3}-\mathrm{A}_{4}\right)$ showed 0.01 level of significant; cucumber leaves are positively correlated $0.86^{*}\left(\mathrm{~A}_{2}-\mathrm{A}_{1}\right)$ at 0.05 level of significant whereas $0.98^{* *}\left(\mathrm{~A}_{3}-\mathrm{A}_{4}\right)$ showed 0.01 level of significant and cucumber fruits are positively correlated $0.90^{*}\left(\mathrm{~A}_{2}-\mathrm{A}_{1}\right)$ at 0.05 level of significant whereas $0.98^{* *}\left(\mathrm{~A}_{3}-\mathrm{A}_{4}\right)$ showed 0.01 level of significant.Potassium content in the soil are positively correlated $0.90^{*}\left(\mathrm{~A}_{2}-\mathrm{A}_{1}\right)$ at 0.05 level of significant whereas $0.99^{* *}\left(\mathrm{~A}_{3}-\mathrm{A}_{4}\right)$ showed 0.01 level of significant; cucumber leaves are positively correlated $0.85^{*}\left(\mathrm{~A}_{2}-\mathrm{A}_{1}\right)$ at 0.05 level of significant whereas $0.97^{* *}\left(\mathrm{~A}_{3}-\mathrm{A}_{4}\right)$ showed 0.01 level of significant and cucumber fruits are positively 
correlated $0.85^{*}\left(\mathrm{~A}_{2}-\mathrm{A}_{1}\right)$ at 0.05 level of significant whereas $0.97^{* *}\left(\mathrm{~A}_{3}-\mathrm{A}_{4}\right)$ showed 0.01 level of significant. Magnesium content in the soil are positively correlated $0.99^{* *}\left(\mathrm{~A}_{2}-\mathrm{A}_{1}\right)$ and $\left(\mathrm{A}_{3}-\mathrm{A}_{4}\right)$ at 0.01 level of significant; cucumber leaves are positively correlated $0.97^{* *}\left(\mathrm{~A}_{2}-\mathrm{A}_{1}\right)$ and $\left(\mathrm{A}_{3}-\mathrm{A}_{4}\right)$ at 0.01 level of significant and cucumber fruits are positively correlated $0.97^{* *}\left(\mathrm{~A}_{2}-\mathrm{A}_{1}\right)$ and $\left(\mathrm{A}_{3}-\mathrm{A}_{4}\right)$ at 0.01 level of significant.Manganese content in the soil are positively correlated $0.98^{* *}\left(\mathrm{~A}_{2}-\mathrm{A}_{1}\right) \& 0.97^{* * *}\left(\mathrm{~A}_{3}-\mathrm{A}_{4}\right)$ at 0.01 level of significant; cucumber leaves are positively correlated $0.96^{* *}$ $\left(\mathrm{A}_{2}-\mathrm{A}_{1}\right)$ and $0.97^{* * *}\left(\mathrm{~A}_{3}-\mathrm{A}_{4}\right)$ at 0.01 level of significant and cucumber fruits are positively correlated $0.96^{* * *}\left(\mathrm{~A}_{2}-\mathrm{A}_{1}\right)$ and $0.99^{* *}\left(\mathrm{~A}_{3}-\mathrm{A}_{4}\right)$ at 0.01 level of significant.Aluminum content in the soil revealed no correlation during summer and monsoon in cement polluted and control plants; leaves revealed no correlation during summer and monsoon in cement polluted and control plants and fruits revealed no correlation during summer and monsoon in cement polluted and control plants.

\section{CONCLUSION}

The statistical prediction of mineral constituents and correlation regarding the studies on the effect of cement pollution revealed that the cultivated crops seriously core reduction in yield, marketable value and quality.

\section{REFERENCES}

[1] Asubiojo. O.I, P.O Aina, A.F Oluwole, W. Arshed, O.A. Akande and N.M Spyrou, 1991. Effects of cement pollution on the elemental composition of soils in the neighbourhood of two factories. Water Air soil. Pollu, 57.819-828

[2] Borka, G. 1986. Effects of cement dust of the growth, development, major metabolic processes and yield of winder barely. In situ and under controlled conditions; Indian J. of Air Pollut. 28, 1132-39.

[3] Krishnamurthy, K.V. and Rajachidambaram, C. 1986. Factors associated with reduction in photosynthetic oxygen Evolution in Cement Dust Coated Leaves; Photosynthetica. 20(2), 164166.

[4] Lerman, S. L. and Darley, E.F. 1974. Particulates in responses of plants to air pollution; Indian J. of Air pollut. Cont. 41, 4208-12.

[5] Nandi, P.K. and Madhoolika, A. and Rao, D.N.EPa/APCA 1987, Symposium on measurement of toxic and related air pollutants. Proceedings, pittsburg APCA-1987. P. 671-676.

[6] Oblisami, G. and Padmanabhan,G, and Padmanabhan, C, Effect of particulate pollutants from cement kilns on cotton plants: Journal of Air pollution Control, 1:9194, 1978.
[7] Prasad M.S.V. Subramanian, R.B and Inamdar J.A. Effect of cement kiln dust on Canjanuscajan (L) Mill.sp. Indian Journal of Environmental Health: 33:11-21, 1991.

[8] Saralabai, V.C and Vivekanandan, 1992 M.Does application of cement kiln-exhaust affect root nodule biochemistry and soil W2-fixing microbes. Applied Biochemistry and Biotechnology part A Enzyme Engineering and Biotechnology, 50): 1-10 